\title{
Pemisahan Itrium dengan Cara Ekstraksi Menggunakan Solven TOPO
}

\section{Separation of Yttrium by Extraction Using TOPO Solvents}

\author{
Tri Handini ${ }^{1 *}$, I Made Sukarna ${ }^{2}$, Anisa Dwi Yuniyanti \\ ${ }^{1}$ Pusat Sains Dan Teknologi Akselerator - BATAN \\ Jl.Babarsari Kotak Pos 6101 ykbb Yogyakarta, Indonesia, 55281 \\ ${ }^{2}$ Jurusan Kimia, Fakultas MIPA - Universitas Negeri Yogyakarta \\ Kampus Karangmalang, Jl. Colombo No. 1 Yogyakarta, Indonesia, 55281 \\ *E-mail: handini@batan.go.id
}

Naskah diterima: 10 Juli 2018, direvisi: 22 November 2018, disetujui: 28 November 2018

DOI: 10.17146/eksplorium.2018.39.2.4419

\begin{abstract}
ABSTRAK
Telah dilakukan proses pemisahan itrium dengan cara ekstraksi menggunakan solven TOPO. Tujuan dari penelitian ini adalah untuk mengetahui kondisi optimum pengaruh variasi konsentrasi ekstraktan, waktu pengadukan, dan keasaman umpan logam tanah jarang serta mengetahui koefisien distribusi (Kd), faktor pisah (FP), dan efisiensi ekstraksi (\%), dengan metode ekstraksi cair-cair. Umpan yang digunakan adalah logam tanah jarang dari pasir senotim. Ekstraktan yang digunakan dalam penelitian adalah TOPO (tri-n-oktilfosfina oksida). Kadar itrium (Y), disprosium (Dy), dan gadolinium (Gd) ditentukan menggunakan spektrometer pendar sinar-X. Kondisi optimum yang diperoleh dari penelitian proses ekstraksi ini meliputi: konsentrasi ekstraktan 20\% TOPO dalam kerosin, waktu pengadukan 15 menit, keasaman umpan 0,5 M. Nilai koefisien distribusi yang diperoleh $\mathrm{Y}=$ 5,61; Dy = 2,06; $\mathrm{Gd}=0,99$. Efisiensi ekstraksi $\mathrm{Y}=85,13 \%, \mathrm{Dy}=67,80 \%, \mathrm{Gd}=50,17 \%$ sedangkan faktor pisah Y-Dy $=2,7186$ dan Y-Gd = 5,6861.
\end{abstract}

Kata kunci: pemisahan, logam tanah jarang, ekstraksi cair-cair

\begin{abstract}
Separation process of yttrium by extraction using TOPO solvents has been done. The purpose of this study is to find out the optimum condition of the variation effect of extractant concentration, stirring time, and acidity of the rare earth feed and to determine the distribution coefficient, separation factor, and extraction efficiency (\%), using the liquid-liquid extraction method. The feed used were rare earth elements of xenotime sand. The extractant used in the research were TOPO (tri-n-octylphosphine oxide). Concentration of yttrium ( $Y$ ), disprosium $(D y)$, and gadolinium $(G d)$ were determined using $X$-ray fluorescene spectrometer. Optimum conditions of the extraction process obtained from this study were: TOPO extractant concentration in kerosene 20\%, stirring time 15 minutes, acidity of feed $0.5 \mathrm{M}$. Obtained value of distribution coefficient $Y=5.61 ; D y=2.06 ; G d=0.99$. For extraction efficiency $Y=85.13 \%, D y=67.80 \%, G d=50.17 \%$ whereas separation factor $Y$-Dy $=2.7186$ and $Y$ $G d=5.6861$
\end{abstract}

Keywords: separation, rare earth elements, liquid-liquid extraction

\section{PENDAHULUAN}

Pasir senotim $\left(\mathrm{YPO}_{4}\right)$ merupakan senyawa logam tanah jarang fosfat (Y LTJ)PO $\mathrm{PO}_{4}$ yang mengandung 54-65\% logam tanah jarang (LTJ) termasuk erbium, serium dan unsur radioaktif yaitu torium. Pasir senotim mempunyai kadar itrium (Y) $\pm 20 \%$ Gadolinium $(\mathrm{Gd}) \pm 1,52 \%$, dan disprosium
(Dy) $\pm 3,34 \%$. Total kadar campuran unsur LTJ dalam pasir senotim antara 55\% sampai $70 \%$ [1].

Itrium (Y) adalah logam yang mempunyai nilai ekonomis yang tinggi, mempunyai kegunaan yang sangat luas, karena secara umum memiliki kekuatan mekanis yang baik, titik leleh relatif tinggi, 
dan memiliki sifat-sifat yang sangat menguntungkan. Sifat-sifat itrium tersebut dimanfaatkan dalam berbagai bidang industri seperti baja, alloy, laser Neodymium-yttriumaluminium garnat (NdY AI), tabung warna $\mathrm{TV}$, campuran tangki reaktor, magnet, dan bahan sel bakar padat (solid oxide fuel cell "SOFC"). Samarium (Sm), Disprosium (Dy) dan Gadolinium $(\mathrm{Gd})$ sebagai batang kendali pada reaktor nuklir karena mempunyai penampang lintang serapan neutron yang tinggi [2].

Ekstraksi pelarut atau ekstraksi cair-cair merupakan distribusi suatu zat telarut (solut) di antara dua fasa cair yang tidak saling bercampur [3]. Dua fasa cair tersebut umumnya adalah fasa air dan fasa organik. Setelah proses ekstraksi, fasa organik adalah larutan yang mengandung banyak solute, yang disebut ekstrak. Fasa organik ini merupakan larutan yang tidak larut dalam air, Sedangkan fasa air adalah larutan yang mengandung sedikit solute disebut rafinat. Metode pemisahan dengan ekstraksi merupakan salah satu metode pemisahan yang dapat dilakukan baik untuk tingkat mikro maupun makro.

Pengembangan terakhir teknik pemisahan dengan cara ekstraksi cair-cair menggunakan D2EHPA. D2EHPA merupakan senyawa organofosfor yang semakin luas pemakaiannya untuk ektraksi itrium (Y) dari LTJ karena mempunyai selektivitas dan efisiensi yang tinggi. Selain D2EHPA, terdapat senyawa organofosfor yang juga memiliki selektivitas tinggi dalam pemisahan itrium (Y) dari LTJ, yaitu tri-n-oktilfosfina oksida (TOPO) [4]-[7].

Ekstraktan atau pelarut organik yang digunakan dalam pemisahan LTJ adalah senyawa organofosfor yang mempunyai gugus fosforil $(\mathrm{P}=\mathrm{O})$. Kekuatan basa gugus $\mathrm{P}=\mathrm{O}$ sangat tergantung pada gugus yang terikat pada atom fosfornya. Ekstraktan sendiri merupakan donor elektron, sedangkan solute atau ion-ion LTJ merupakan aseptor elektron. Contoh ekstraktan tersebut adalah di-(2-ethyl hexyl) phosphoric acid (D2EHPA), tributil fosfat (TBP) dan tri-noktilfosfina oksida (TOPO) [8]-[10].

Pengencer untuk pelarut organik yang sering digunakan untuk ekstraksi unsur-unsur LTJ dalam campuran ekstraktan adalah dodekan, kerosin, dan toluene [3].

Ekstraksi pelarut didasarkan pada prinsip hukum distribusi Nerst, yang menyatakan bahwa ke dalam dua pelarut yang tidak saling bercampur dimasukkan solute yang dapat larut dalam kedua pelarut tersebut, maka akan terjadi pembagian solute dengan perbandingan tertentu. Perbandingan konsetrasi solute di dalam kedua pelarut tersebut tetap, dan merupakan suatu tetapan pada suhu tetap. Tetapan tersebut disebut tetapan distribusi atau koefisien distribusi (Kd). Tetapan distribusi dinyatakan dengan persamaan [3]:

$$
\mathrm{Kd}=\frac{C o}{C a}
$$

Keterangan:

$\mathrm{Kd}=$ Koefisien distribusi

$\mathrm{Co}=$ Konsentrasi solute pada pelarut organik

$\mathrm{Ca}=$ Konsentrasi solute pada pelarut air

Dari nilai koefisien distribusi tersebut dapat untuk menentukan faktor pisah (FP) dari unsur satu dengan unsur lainnya. Faktor pisah digunakan sebagai ukuran keberhasilan suatu proses ekstraksi dan mengetahui kondisi optimum ekstraksi. Faktor pisah (FP) yakni perbandingan antara koefisien distribusi suatu unsur dengan koefisien distribusi unsur yang lainnya. Persamaan untuk memperoleh FP adalah:

$$
F P=\frac{K d_{1}}{K d_{2}}
$$


Keterangan:

$K d_{1}=$ Koefisien distribusi unsur 1

$K d_{2}=$ Koefisien distribusi unsur 2

Efektifitas dalam proses ekstraksi dapat dinyatakan dengan persen solute yang terekstrak yang dapat diperoleh dengan persamaan sebagai berikut [11]:

$$
E=\frac{M x}{M} X 100 \%
$$

Keterangan:

$M x$ = Massa terekstrak

$M$ = Massa umpan mula-mula

$E \quad=$ Efisiensi ekstraksi (\%)

\section{METODOLOGI}

\section{Alat dan Bahan}

Alat yang digunakan adalah peralatan gelas laboratorium, timbangan, pengaduk dan pemanas (Ikamag). Bahan yang digunakan adalah konsentrat itrium (PSTA), $\mathrm{HNO}_{3} 65 \%$ (Merck), TOPO (Merck), Kerosin (Fisher).

\section{Cara Kerja}

1. Variasi ekstraksi konsentrasi ekstraktan TOPO (tri-n-oktil fosfina oksida)

Proses ekstraksi menggunakan larutan umpan LTJ 26,25 gram dalam $\mathrm{HNO}_{3}$ 0,5 M sebagai fasa air. Proses ekstraksi dilakukan dengan cara mengambil masing-masing 10 mL umpan ditambah $10 \mathrm{~mL}$ TOPO (\% b/v) dalam pengencer kerosin dengan variasi konsentrasi $5 \%$; $10 \%$; $15 \%$, 20\%, dan $25 \%$, pengadukan pada kecepatan $250 \mathrm{rpm}$, waktu pengadukan 15 menit, perbandingan FA : FO $=1: 1$. Dua lapisan hasil ekstraksi yaitu fasa air dan fasa organik kemudian dipisahkan. Rafinat (fasa air) dianalisis menggunakan alat spektrometer pendar sinar-X (MCA ORTEC, $\mathrm{hV}=50 \mathrm{eV}$, sumber $241 \mathrm{Am}$, waktu cacah = 300 detik). Dari hasil percobaan diperoleh kondisi optimum konsentrasi ekstraktan yang dipakai untuk proses selanjutnya.
2. Variasi waktu pengadukan

Untuk waktu pengadukan dilakukan dengan cara pengadukan umpan dan ekstraktan divariasi 5, 10, 15, 20, dan 30 menit. Diambil larutan umpan $10 \mathrm{~mL}$ masingmasing dimasukkan ke dalam larutan ekstraktan 20\% TOPO-kerosin, pengadukan pada kecepatan $250 \mathrm{rpm}$, perbandingan FA : $\mathrm{FO}=1: 1$. Fasa air dipisahkan dari fasa organik untuk di analisis kadar Y, Dy, dan Gd dengan alat spektrometer pendar sinar-X.

\section{Variasi keasaman umpan}

Diambil larutan umpan $10 \mathrm{~mL}$ masingmasing dengan molaritas $0,5,1,2,3$, dan 4 $M$ yang telah dibuat diekstraksi menggunakan TOPO $20 \%$ b/v dalam kerosin. selama 15 menit, kecepatan pengadukan $250 \mathrm{rpm}$, perbandingan FA : FO = 1 : 1. Pemilihan TOPO $20 \% \mathrm{~b} / \mathrm{v}$ dalam kerosin dan waktu pengadukan 15 menit merupakan kondisi optimum pada percobaan sebelumnya. Hasil ekstraksi berupa fasa organik dan fasa air yang kemudian dipisahkan. Rafinat (fasa air) selanjutnya dianalisa dengan spektrometer pendar sinar-X

\section{HASIL DAN PEMBAHASAN}

1. Variasi ekstraksi konsentrasi ekstraktan TOPO

Harga koefisien distribusi $(\mathrm{Kd})$ dan faktor pisah (FP) pada ekstraksi variasi ekstraktan TOPO dapat dilihat pada Tabel 1. Semakin besar konsentrasi TOPO (\% b/v) maka harga $\mathrm{Kd}$ juga semakin meningkat, karena semakin tinggi konsentrasi TOPO (\% $\mathrm{b} / \mathrm{v})$ maka semakin banyak membentuk kompleks dengan logam. Semakin besar konsentrasi ekstraktan maka semakin baik mengekstraksi unsur-unsur dalam umpan, yang ditandai naiknya harga $\mathrm{Kd}$, tetapi setelah mencapai konsentrasi tertentu nilai $\mathrm{Kd}$ akan semakin menurun karena pada 
konsentrasi ekstraktan yang semakin besar perpindahan solut dari fasa air ke fasa organik akan semakin sulit. Hal ini dapat dijelaskan melalui persamaan Stokes-Einstein [12]:

$$
\mathrm{D}_{\mathrm{A} . \mathrm{B}}=\frac{6 K T}{6 \pi r \mu_{B}}
$$

\section{Keterangan:}

$\mathrm{D}_{\mathrm{A} . \mathrm{B}}=$ difusivitas dari $\mathrm{A}$ di dalam larutan encer dalam $\mathrm{B}, \mathrm{cm}^{2} / \mathrm{s}$

$k=$ konstanta Boltzman $=1,38 \times 10^{-23} \mathrm{~J} / \mathrm{K}$

$T=$ suhu, ${ }^{\circ} \mathrm{K}$

$r \quad=$ jari-jari partikel zat terlarut, $\mathrm{cm}$

$\mu_{B} \quad=$ viskositas pelarut, $\mathrm{cP}$

Tabel 1. Hubungan konsentrasi TOPO (\% b/v) dalam kerosin terhadap koefisien distribusi $(\mathrm{Kd})$ dan faktor pisah (FP) Y, Dy, dan Gd.

\begin{tabular}{cccccc}
\hline \multirow{2}{*}{$\begin{array}{c}\text { TOPO } \\
(\% \mathrm{~b} / \mathrm{v})\end{array}$} & \multicolumn{2}{c}{$\begin{array}{c}\text { Koefisien Distribusi } \\
(\mathrm{Kd})\end{array}$} & \multicolumn{2}{c}{$\begin{array}{c}\text { Faktor Pisah } \\
(\mathrm{FP})\end{array}$} \\
\cline { 2 - 6 } & Y & Dy & Gd & Y-Dy & Y-Gd \\
\hline 5 & 0,44 & 1,26 & 1,11 & 0,35 & 0,40 \\
10 & 0,39 & 1,38 & 0,96 & 0,28 & 0,41 \\
15 & 0,92 & 1,96 & 1,03 & 0,48 & 0,89 \\
20 & 5,61 & 2,06 & 0,99 & 2,72 & 5,67 \\
25 & 5,21 & 1,96 & 0,91 & 2,66 & 5,73 \\
\hline
\end{tabular}

Keterangan: volume FA $=10 \mathrm{~mL}, \mathrm{FO}=\mathrm{TOPO}(5,10$, 15,20, dan $25 \%$ ) b/v dalam kerosin dengan perbandingan FA : FO = $1: 1$, kecepatan pengadukan $250 \mathrm{rpm}$, dan waktu pengadukan 15 menit.

Dari persamaan (4) dapat diketahui bahwa difusivitas berbanding terbalik dengan viskositas pelarut, sehingga semakin besar viskositas pelarut maka akan semakin mengalami kesulitan untuk berdifusi dari fasa air ke fasa organik, sehingga menurunkan harga Kd. Faktor pisah (FP) pada kondisi optimum untuk Y-Dy yaitu sebesar 2,72 sedangkan Y-Gd relatif besar yaitu 5,67. Hal ini menunjukan bahwa pada konsentrasi TOPO 20\% (b/v) dalam kerosin antara Y dan Dy belum terpisah cukup baik, tetapi berbeda antara $\mathrm{Y}$ dengan $\mathrm{Gd}$ yang dapat terpisah dengan baik.
Data hubungan konsentrasi TOPO (\% $\mathrm{b} / \mathrm{v}$ ) dalam kerosin terhadap efisiensi (\%) Y, Dy dan Gd disajikan dalam Tabel 2.

Tabel 2. Hubungan konsentrasi TOPO (\% b/v) dalam kerosin terhadap efisiensi (\%) Y, Dy dan Gd.

\begin{tabular}{cccc}
\hline TOPO & \multicolumn{3}{c}{ Efisiensi (\%) } \\
\cline { 2 - 4 }$(\% \mathrm{~b} / \mathrm{v})$ & $\mathrm{Y}$ & $\mathrm{Dy}$ & $\mathrm{Gd}$ \\
\hline 5 & 31,84 & 57,18 & 54,19 \\
10 & 29,88 & 59,98 & 51,07 \\
15 & 50,28 & 68,40 & 53,24 \\
20 & 85,13 & 67,80 & 50,17 \\
25 & 84,17 & 66,66 & 48,11
\end{tabular}

Keterangan: volume $\mathrm{FA}=10 \mathrm{~mL}, \mathrm{FO}=\mathrm{TOPO}(5,10$, $15,20$, dan $25 \%) \mathrm{b} / \mathrm{v}$ dalam kerosin dengan perbandingan $\mathrm{FA}: \mathrm{FO}=1: 1$, kecepatan pengadukan $250 \mathrm{rpm}$, dan waktu pengadukan 15 menit.

Kurva hubungan konsentrasi TOPO (\% $\mathrm{b} / \mathrm{v}$ ) dalam kerosin terhadap efisiensi (\%) Y, Dy dan Gd dapat dilihat pada Gambar 2.Dari Tabel 2 dan Gambar 2 dapat diketahui efisiensi tertinggi diperoleh pada konsentrasi TOPO (\% b/v) sebesar $20 \%$ dalam kerosin. Pada konsentrasi TOPO 20\% dalam kerosin sudah dapat mengekstrak Y secara optimal dan cukup terpisah dengan Dy dan Gd.

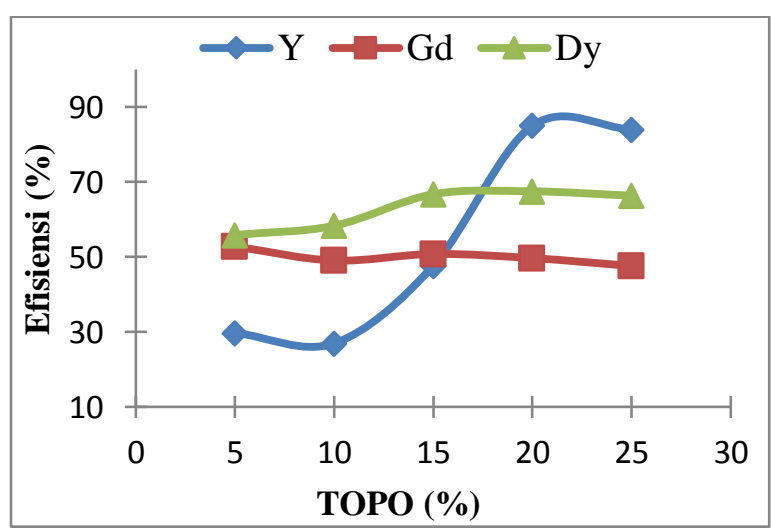

Gambar 2. Hubungan konsentrasi TOPO ( $\%$ b/v) dalam kerosin terhadap efisiensi (\%) Y, Dy, dan Gd.

\section{Variasi waktu pengadukan}

Larutan umpan LTJ diekstraksi dengan TOPO 20\% (b/v) dalam kerosin pada variasi waktu pengadukan $10,15,20,30$, dan 40 menit. Konsentrasi TOPO 20\% (b/v) dalam 
kerosin merupakan kondisi optimum ekstraktan TOPO pada peneltian sebelumnya. Hasil ekstraksi berupa dua lapisan fasa air dan fasa organik yang kemudian dipisahkan. Rafinat (fasa air) selanjutnya dianalisis dengan spektrometer pendar sinar-X.

Proses pengadukan juga mempengaruhi proses difusi dan viskositas. Semakin lama waktu pengadukan maka akan semakin besar viskositas pelarut, sehingga akan semakin mengalami kesulitan untuk berdifusi dari fasa air ke fasa organik. Hal tersebut akan dapat menurunkan harga $\mathrm{Kd}$, sesuai pada persamaan 1. Harga koefisien distribusi (Kd), Y, Dy, dan Gd dan faktor pisah (FP) pada berbagai variasi waktu pengadukan untuk TOPO 20\% (b/v) dalam kerosin disajikan pada Tabel 3.

Tabel 3. Hubungan waktu pengadukan (menit) terhadap koefisien distribusi (Kd) dan faktor pisah (FP) Y, Dy dan Gd untuk TOPO 20\% (b/v) dalam kerosin.

\begin{tabular}{cccccr}
\hline \multirow{2}{*}{$\begin{array}{c}\text { Waktu } \\
\text { (menit) }\end{array}$} & \multicolumn{3}{c}{$\begin{array}{c}\text { Koefisien Distribusi } \\
(\mathrm{Kd})\end{array}$} & \multicolumn{3}{c}{$\begin{array}{c}\text { Faktor Pisah } \\
(\mathrm{FP})\end{array}$} \\
\cline { 2 - 6 } & $\mathrm{Y}$ & $\mathrm{Dy}$ & $\mathrm{Gd}$ & Y-Dy & Y-Gd \\
\hline 10 & 4,02 & 3,43 & 0,71 & 1,17 & 5,69 \\
15 & 5,62 & 4,03 & 0,99 & 1,39 & 5,69 \\
20 & 3,42 & 1,60 & 0,30 & 2,13 & 11,32 \\
30 & 3,32 & 1,89 & 0,45 & 1,76 & 7,46 \\
40 & 3,35 & 3,73 & 0,32 & 0,90 & 10,69 \\
\hline
\end{tabular}

Keterangan: volume FA $=10 \mathrm{~mL}, \mathrm{FO}=$ TOPO $20 \%$ (b/v) dalam kerosin dengan perbandingan FA : FO = 1 : 1, kecepatan pengadukan $250 \mathrm{rpm}$, dan waktu pengadukan $(10,15,20,30$, dan 40 menit).

Waktu pengadukan berpengaruh terhadap kenaikan nilai $\mathrm{Kd}$, waktu kontak antara umpan dengan ekstraktan TOPO dalam kerosin akan mempengaruhi distribusi Y, Dy, dan Gd ke dalam fasa organik. Semakin lama waktu kontak antara fasa air dengan fasa organik selama proses ekstraksi maka semakin banyak pula jumlah unsur-unsur yang terikat oleh TOPO. Namun pada saat tercapai keadaan setimbang, jumlah unsur- unsur yang terekstrak tidak lagi dipengaruhi oleh waktu. Waktu pengadukan merupakan salah satu parameter yang perlu dilakukan karena menentukan terjadinya reaksi dan terbentuknya hasil reaksi. Setelah mencapai keadaan setimbang akan diperoleh nilai koefisien distribusi. Sesuai dengan kecepatan reaksi, berkurangnya reaktan, atau bertambahnya hasil reaksi secara matematis dapat dinyatakan sebagai:

$$
\begin{aligned}
& -\frac{d[A]}{d t}=k[A] \\
& \int_{[A]_{o}}^{[A]} \frac{d[A]}{[A]}=-\int_{0}^{t} k \cdot d t \\
& {[A]=[A]_{o} \cdot e^{-k t}}
\end{aligned}
$$

dengan:

[A] = konsentrasi A sesudah bereaksi, $\mathrm{mol} / \mathrm{cm}^{3}$.

$[\mathrm{A}]_{\mathrm{o}}=$ konsentrasi A mula-mula (sebelum bereaksi), $\mathrm{mol} / \mathrm{cm}^{3}$.

$\mathrm{k}=$ konstanta kecepatan reaksi, $\mathrm{mol} / \mathrm{cm}^{3}$.

$\mathrm{t}=$ waktu reaksi, dtk.

Bila reaksi yang berlangsung orde satu maka akan diperoleh persamaan [A] $=[A]_{o} \cdot e^{-k t}$. Persamaan ini menunjukkan bahwa dalam reaksi orde pertama konsentrasi reaktan akan berkurang secara eksponensial terhadap waktu sedangkan untuk produk akan bertambah. Pada waktu pengadukan 15 menit, unsur $\mathrm{Y}$ dan Dy merupakan unsur yang terekstrak paling banyak daripada Gd, sehingga untuk Y-Dy memiiki faktor pisah (FP) yang kecil. Faktor pisah yang kecil tersebut menunjukan bahwa pada waktu pegadukan 15 menit belum cukup baik dalam pemisahan unsur $\mathrm{Y}$ dengan Dy. Sedangkan untuk Y-Gd sudah relatif baik dalam pemisahannya.

Data hubungan waktu pengadukan (menit) terhadap efisiensi (\%) Y, Dy, dan Gd untuk TOPO 20\% (b/v) dapat dilihat pada Gambar 4. 


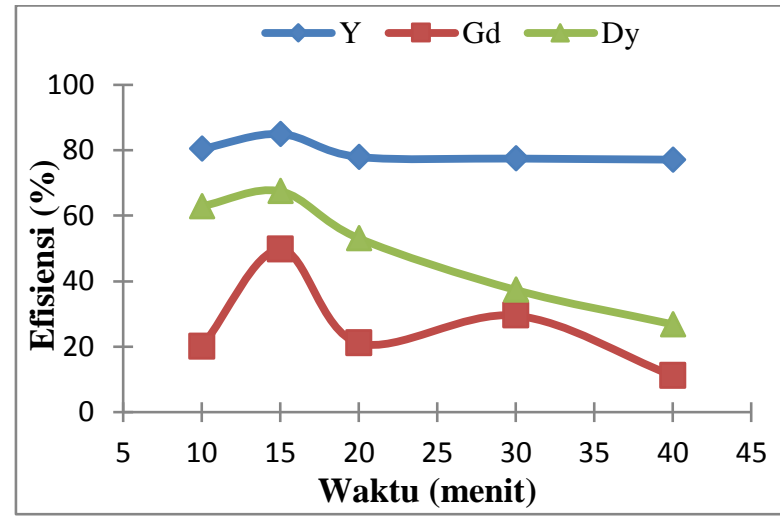

Gambar 4. Hubungan waktu pengadukan (menit) terhadap efisiensi (\%) Y, Dy dan Gd untuk TOPO 20\% (b/v) dalam kerosin.

Dari Gambar 4 dapat diketahui efisiensi (\%) untuk Y, Dy, dan Gd meningkat pada pengadukan 10-15 menit, dan menurun pada pengadukan setelah 15 menit, sehingga waktu pengadukan yang relatif baik digunakan untuk ekstraksi menggunakan TOPO 20\% adalah waktu 15 menit.

\section{Variasi keasaman umpan}

Larutan umpan dengan molaritas 0,5, 1, 2, 3, dan $4 \mathrm{M}$ yang telah dibuat diekstraksi menggunakan TOPO 20\% (b/v) dalam kerosin selama 15 menit. Pemilihan TOPO $20 \%$ (b/v) dalam kerosin dan waktu pengadukan 15 menit merupakan kondisi optimum pada percobaan sebelumnya. Hasil ekstraksi berupa fasa organik dan fasa air yang kemudian dipisahkan. Rafinat (fasa air) selanjutnya dianalisis dengan spektrometer pendar sinar-X.

Diperoleh kadar unsur tertinggi pada konsentrasi keasaman umpan $\mathrm{HNO}_{3}$ 0,5 M. Penambahan konsentrasi keasaman umpan $\mathrm{HNO}_{3}$ menyebabkan terjadinya penurunan kadar unsur yang cukup signifikan. Oleh karena itu, konsentrasi keasaman umpan $\mathrm{HNO}_{3}$ 0,5 $\mathrm{M}$ merupakan kondisi yang paling optimal untuk ekstraksi umpan LTJ menggunakan TOPO 20\% b/v dalam kerosin. Konsentrasi keasaman yang relatif tinggi reaksi yang terjadi adalah pembentukan komplek, sedangkan pada konsentrasi rendah reaksi yang terjadi adalah pertukaran ion.Reaksi yang terjadi antara logam dengan TOPO pada keasaman rendah mengikuti reaksi pertukaran kation sebagai berikut [4]:

$\mathrm{H}^{+}+\mathrm{NO}^{-} \rightleftarrows \mathrm{HNO}_{3}$

$\mathrm{HNO}_{3}(\mathrm{a})+\mathrm{TOPO}(\mathrm{o}) \rightleftarrows$

$\mathrm{HNO}_{3}$.TOPO (o)

$$
\begin{array}{r}
\mathrm{M}^{3+}+4 \mathrm{HNO}_{3} \cdot \mathrm{TOPO}(\mathrm{o}) \rightleftarrows \\
\mathrm{M}\left(\mathrm{NO}_{3}\right) \cdot 4(\mathrm{TOPO})(\mathrm{o})+3 \mathrm{H}^{+}
\end{array}
$$

$\mathrm{M}=$ unsur $\mathrm{Y}, \mathrm{Dy}, \mathrm{dan} \mathrm{Gd}$

Dari persamaan reaksi di atas tampak bahwa apabila keasaman larutan bertambah, maka reaksi bergeser kekiri, hal ini mengakibatkan nilai $\mathrm{Kd}$ menjadi turun. Terlihat bahwa terjadi mekanisme ekstraksi pertukaran kation dikarenakan $\mathrm{M}$ sebagai logam menggantikan $\mathrm{H}$ pada $\mathrm{HNO}_{3}$.TOPO. Pada mekanisme ini dapat dilihat bahwa pada konsentrasi $\mathrm{HNO}_{3}$ (setelah 0,5 M) mengalami penurunan nilai $\mathrm{Kd}$ seperti yang disajikan pada Tabel 4. Hal ini juga didukung dari nilai faktor pisah (FP) antara Y-Dy dan Y-Gd yang tinggi. Faktor pisah yang tinggi tersebut menunjukan bahwa pada keasaman umpan konsentrasi $\mathrm{HNO}_{3} \quad 0,5 \mathrm{M}$ untuk TOPO 20\% (b/v) sudah baik dalam pemisahan unsur $\mathrm{Y}$ dari Dy dan Gd. Harga koefisien distribusi (Kd) dan faktor pisah (FP) disajikan pada Tabel 4. Sedangkan untuk hubungan konsentrasi $\mathrm{HNO}_{3}$ terhadap efisiensi Y, Dy, dan Gd untuk TOPO 20\% (b/v) dalam kerosin disajikan pada Tabel 5.

Semakin pekat $\mathrm{HNO}_{3}$ semakin mudah umpan yang terlarut. Meskipun molaritas $\mathrm{HNO}_{3}$ yang meningkat dapat meningkatkan reaktivitas pembentukan kompleks, tetapi pada keasaman yang terlalu tinggi akan menyebabkan menurunnya kemapuan TOPO, sehingga menurunkan efisiensi ekstraksi [4]. 
Tabel 4. Hubungan konsentrasi $\mathrm{HNO}_{3}(\mathrm{M})$ terhadap koefisien distribusi (Kd) dan faktor pisah (FP) Y, Dy, dan Gd untuk TOPO 20\% (b/v) dalam kerosin.

\begin{tabular}{clrlrr}
\hline $\mathrm{HNO}_{3}$ & \multicolumn{2}{c}{$\begin{array}{c}\text { Koefisien Distribusi } \\
(\mathrm{Kd})\end{array}$} & \multicolumn{3}{c}{$\begin{array}{c}\text { Faktor Pisah } \\
(\mathrm{FP})\end{array}$} \\
\cline { 2 - 6 } & \multicolumn{1}{c}{ Y } & Dy & Gd & Y-Dy & Y-Gd \\
\hline 0,5 & 5,61 & 2,06 & 0,99 & 2,72 & 5,69 \\
1 & 0,15 & 1,80 & 0,63 & 0,09 & 0,24 \\
2 & 0,03 & $\approx 0$ & 0,19 & - & 0,17 \\
3 & 0,03 & 0,29 & 0,38 & 0,11 & 0,08 \\
4 & 0,01 & $\approx 0$ & 0,28 & - & 0,05
\end{tabular}

Keterangan: volume FA $=10 \mathrm{~mL}, \mathrm{FO}=\mathrm{TOPO} 20 \%$ $\mathrm{b} / \mathrm{v}$ dalam kerosin dengan perbandingan $\mathrm{FA}: \mathrm{FO}=1$ : 1, kecepatan pengadukan $250 \mathrm{rpm}$, dan waktu pengadukan 15 menit.

Tabel 5. Hubungan konsentrasi $\mathrm{HNO}_{3}$ (M) terhadap efisiensi (\%) Y, Dy dan Gd untuk TOPO 20\% (b/v) dalam kerosin.

\begin{tabular}{cccc}
\hline $\mathrm{HNO}_{3}$ & \multicolumn{3}{c}{ Efisiensi (\%) } \\
\cline { 2 - 4 }$(\mathrm{M})$ & $\mathrm{Y}$ & $\mathrm{Dy}$ & $\mathrm{Gd}$ \\
\hline 0,5 & 85,13 & 67,80 & 50,17 \\
1 & 13,77 & 65,18 & 39,54 \\
2 & 3,21 & $\approx 0$ & 16,65 \\
3 & 3,17 & 23,75 & 28,62 \\
4 & 1,40 & $\approx 0$ & 22,03 \\
\hline
\end{tabular}

Keterangan: volume FA $=10 \mathrm{~mL}, \mathrm{FO}=\mathrm{TOPO} 20 \%$ $\mathrm{b} / \mathrm{v}$ dalam kerosin dengan perbandingan $\mathrm{FA}: \mathrm{FO}=1$ : 1, kecepatan pengadukan $250 \mathrm{rpm}$, dan waktu pengadukan 15 menit.

Semakin pekat $\mathrm{HNO}_{3}$ semakin mudah umpan yang terlarut. Meskipun molaritas $\mathrm{HNO}_{3}$ yang meningkat dapat meningkatkan reaktivitas pembentukan kompleks, tetapi pada keasaman yang terlalu tinggi akan menyebabkan menurunnya kemapuan TOPO, sehingga menurunkan efisiensi ekstraksi [4].

\section{KESIMPULAN}

Hasil penelitian ekstraksi Y, Dy, dan Gd dari konsentrat itrium dengan solven TOPO diperoleh kesimpulan bahwa kondisi terbaik diperoleh pada keasaman umpan 0,5 M, waktu ekstraksi 15 menit, perbandingan FA : FO = $1: 1$. Pada kondisi ini diperoleh nilai koefisien distribusi $\mathrm{Y}=5,61$; $\mathrm{Dy}=2,06$; $\mathrm{Gd}$ $=0,99$. Untuk efisiensi ekstraksi $\mathrm{Y}=85,13 \%$,
Dy $=67,80 \%, \mathrm{Gd}=50,17 \%$ sedangkan faktor pisah Y-Dy $=2,7186$ dan Y-Gd = 5,6861.

\section{UCAPAN TERIMA KASIH}

Pada kesempatan ini penulis mengucapkan terima kasih kepada pihak manajemen PSTA yang telah memberikan fasilitas dan mendanai penelitian ini. Juga kepada Bapak Dwi Biyantoro dan Bapak Sri Sukmajaya yang telah membantu penelitian ini.

\section{DAFTAR PUSTAKA}

[1] Supardi, "Dijesti Bertingkat pada Pemisahan Konsentrat Y2O3 dari Pasir Senotim," Universitas Gadjah Mada, 2002.

[2] A. N. Bintarti, Bambang, and M. V. Purwani, "Ekstraksi untuk Memisahkan Unsur-Unsur dalam Konsentrat Logam Tanah Jarang dari Pasir Senotim," in Prosiding Pertemuan dan Presentasi Ilmiah Penelitian Dasar Ilmu Pengetahuan dan Teknologi Nuklir, P3TMBATAN, 2002, pp. 257-261.

[3] Soebagio, E. Budiasih, M. S. Ibnu, H. R. Widarti, and Munzil, Kimia Analitik II. Malang: Universitas Negeri Malang, 2003.

[4] D. Biyantoro and M. V. Purwani, "Optimasi Pemisahan Zr-Hf dengan Cara Ekstraksi Memakai Solven TOPO," J. Teknol. Bahan Nukl., vol. 9, no. 1, pp. 34-45, 2013.

[5] D. Biyantoro, "Ekstraksi Itrium dari Konsentrat Senotim Menggunakan D2EHPA - Dodekan," in Prosiding PPI - PDIPTN, 2007, pp. 42-48.

[6] T. Handini, Bambang, and S. Sukmajaya, "Ekstraksi Y, Dy, Gd dari Konsentrat Itrium dengan Solven TBP dan D2EHPA," J. Iptek Nukl. Ganendra, vol. 20, no. 1, pp. 49-55, 2017.

[7] R. Sulistyani, W. R. Pusparini, and D. Biyantoro, "Pemisahan Y, Dy, Gd Hasil Ekstraksi dari Konsentrat Itrium Menggunakan Kolom Penukar Ion," in Prosiding PPI - PDIPTN, 2016, pp. 110 114.

[8] S. Prakash, Advanced Chemistry of Rare Elements. New Delhi: S. Chand Ltd, 1975.

[9] Sato, "The Extraction of Uranium (IV), Yttrium(III), and Lantanum(III) from Hydrochloric Solution by Acid Organophosphorus Cmpounds," in Proceeding of the International Symposium on Actinidel Lanthanide Separation, 1984. 
[10] Suprihati, Purwoto, and Bambang, "Ekstraksi Konsentrat Logam Tanah Jarang dengan Topo Dalam HCl," in Prosiding Seminar Penelitian dan Pengelolaan Perangkat Nuklir, 2008, pp. 221-224.

[11] M. V. Purwani, Suyanti, and A. W. Muhadi, "Ekstraksi Konsentrat Neodimium Memakai Asam di- 2 - etil Heksil Fosfat," in Seminar Nasional IV SDM Teknologi Nuklir, 2008, pp. 439-447.
[12] J. R. Welty, C. E. Wicks, R. E. Wilson, and G. Rorrer, Dasar-Dasar Fenomena Transport, 4th ed. Jakarta: Erlangga, 2004. 